\title{
Profil lipid pada wanita dengan sindrom koroner akut
}

\author{
Ronaldi \\ Ike Adriana \\ Monique Rotty \\ Reginald L. Lefrandt \\ Agnes L. Panda
}

\author{
Bagian Ilmu Penyakit Jantung dan Pembuluh Darah Fakultas Kedokteran \\ Universitas Sam Ratulangi BLU RSUP Prof. Dr. R. D. Kandou Manado \\ Email: ronaldi08@yahoo.com
}

\begin{abstract}
Females with acute coronary syndrome (ACS) display different characteristics from the opposite gender. Currently, only limited data were available regarding the characteristic of ACS in females, especially in Manado. This study aimed to obtain the lipid profile of females with ACS at Prof. Dr. R. D. Kandou Hospital Manado in 2012-2013. This was a descriptive retrospective study with a cross sectional design. Subjects were all female patients with ACS who were admitted to Prof. Dr. R. D. Kandou Hospital Manado from January 2012 to December 2013. Data were collected based on the medical record. Exclusion criteria included incomplete data and non-ACS as the main diagnosis. There were 81 women as subjects in this study. The mean age was $61.59 \pm 10.78$ years. Unstable angina pectoris, non-ST elevation myocardial infarction, ST elevation myocardial infarction were found in 38 (46.9\%), 15 (18.5\%), and 28 (34.6\%) patients consecutively. Mean value of total cholesterol, low density lipoprotein (LDL), high density lipoprotein (HDL), and trygliserida levels were as follows: $218.17 \pm 48.88,145.91 \pm 47.30,39.72 \pm 15.99$, and $153 \pm 65.55 \mathrm{mg} / \mathrm{dl}$. High level of total cholesterol, LDL, and trygliserida were found in $52(64.2 \%), 50(61.7 \%), 14(17.3 \%)$ patients consecutively meanwhile low HDL level was found in 51(63\%) patients. Diabetes mellitus and hypertension were found in $24(29.6 \%)$ and $58(71.6 \%)$ patients. The mean length of stay was $8.44 \pm 4.36$ days.
\end{abstract}

Keywords: female, lipid profile, acute coronary syndrome

\begin{abstract}
Abstrak: Wanita dengan sindrom koroner akut (SKA) menampilkan karakteristik yang berbeda daripada laki-laki dengan SKA. Sampai saat ini, masih tersedia sedikit data mengenai karakteristik SKA pada wanita. Penelitian ini bertujuan mendapatkan gambaran profil lipid pada wanita dengan SKA yang dirawat di RSUP Prof. Dr. R. D. Kandou. Jenis penelitian ini deskriptif retrospektif dengan desain potong lintang. Subyek penelitian ialah pasien wanita dengan SKA yang dirawat di RSUP Prof. Dr. R. D. Kandou, Manado dari Januari 2012Desember 2013. Data dikumpulkan dari rekam medis. Kriteria eksklusi meliputi data yang tidak lengkap dan diagnosis selain SKA sebagai diagnosis utama. Hasil penelitian

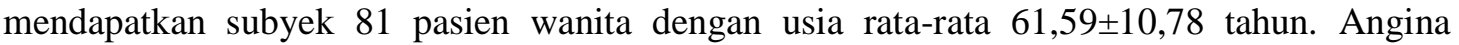
pektoris tak stabil ditemukan pada 38 pasien (46,9\%), non-ST segment elevation myocardial infarction pada 15 pasien (18,5\%), dan ST segment elevation myocardial infarction pada 28 pasien $(34,6 \%)$. Kadar rerata kolesterol total, low density lipoprotein (LDL), high density

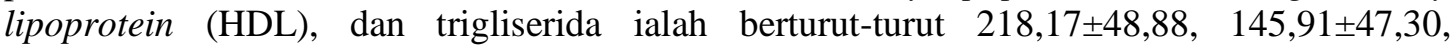
$39,72 \pm 15,99$, dan $153 \pm 65,55 \mathrm{mg} / \mathrm{dl}$. Kadar kolesterol total, LDL, trigliserida yang tinggi ditemukan berturut-turut pada 52 pasien $(64,2 \%), 50$ pasien $(61,7 \%)$, dan 14 pasien $(17,3 \%)$ sedangkan kadar HDL yang rendah ditemukan pada 51 pasien $(63 \%)$. Diabetes melitus dan hipertensi ditemukan pada 24 pasien $(29,6 \%)$ dan 58 pasien $(71,6 \%)$. Rerata lama perawatan di rumah sakit ialah $8,44 \pm 4,36$ hari.
\end{abstract}

Kata kunci: wanita, profil lipid, sindrom koroner akut 
Sindrom Koroner Akut (SKA) merupakan suatu keadaan gawat darurat dari Penyakit Jantung Koroner (PJK) dan terdiri dari sekelompok gejala klinis yang berhubungan dengan iskemik miokard akut serta mencakup berbagai kondisi klinis, mulai dari angina pektoris tidak stabil, infark miokard tanpa elevasi segmen ST (non-ST segment elevation myocardial infarction, NSTEMI) dan infark miokard dengan elevasi segmen ST (ST segment elevation myocardial infarction, STEMI). ${ }^{1,2}$ Penyakit kardiovaskuler telah menjadi penyebab kematian nomor satu di dunia, hal ini menunjukkan lebih banyak orang meninggal setiap tahunnya karena penyakit kadiovaskuler dari pada penyebab lainnya. ${ }^{3}$

Penyakit kardiovaskuler yang diperkirakan akan menjadi penyebab utama kematian di negara-negara maju dan negara berkembang pada tahun 2020 ialah penyakit jantung koroner (PJK) yang berhubungan dengan mortalitas dan morbiditas yang tinggi. Manifestasi klinis penyakit ini meliputi silent ischemia, angina pektoris stabil, angina pektoris tidak stabil, infark miokard, gagal jantung, dan kematian mendadak.

Di Indonesia PJK merupakan pembunuh nomor satu dan jumlah kejadiannya terus meningkat dari tahun ke tahun. Data statistik menunjukkan bahwa pada tahun 1992 persentase penderita PJK di Indonesia $16,5 \%$ dan pada tahun 2000 melonjak menjadi $26,4 \%$. Tiga dari 1.000 penduduk Indonesia menderita PJK. ${ }^{4,5}$

Data distribusi penyebab kematian di Indonesia tahun 1995 hingga 2007 menunjukkan kelompok penyakit tidak menular merupakan kelompok penyakit penyebab kematian tertinggi dibandingkan dengan kelompok penyakit lainnya. Penyakit yang termasuk dalam kelompok penyakit tidak menular ini meliputi kanker, penyakit jantung, stroke, diabetes melitus (DM) dan lainnya. Kelompok penyakit tidak menular merupakan kasus rawat inap terbanyak di rumah sakit di Indonesia dari tahun $2009-2010$, yaitu $40,53 \%$ pada tahun 2009 dan 43,03\% pada tahun 2010. Penyakit jantung merupakan kasus serta penyebab kematian terbanyak dari kelompok penyakit tidak menular pada tahun 2009 dan $2010 .^{6}$

Penyakit jantung koroner dapat dicegah dengan mengatasi faktor-faktor risiko PJK yang ditemukan seperti penggunaan tembakau, diet yang tidak sehat, obesitas, aktivitas fisik yang kurang, hipertensi, DM, dan abnormalitas kadar lipid. Faktor risiko yang berpengaruh pada PJK dibagi menjadi dua yaitu faktor risiko yang tidak dapat dikendalikan (usia, jenis kelamin, riwayat keluarga) dan faktor risiko yang dapat dikendalikan (merokok, obesitas, hipertensi, dislipidemia, DM, dan kurang berolahraga). ${ }^{7,9}$

Dislipidemia yang merupakan salah satu dari faktor risiko penyakit PJK adalah abnormalitas profil lipid di darah yang dapat memengaruhi proses aterosklerotik. Menurut WHO, dislipidemia merupakan faktor risiko mayor untuk terjadinya PJK yang ditandai dengan tingginya kadar kolesterol total, low density lpoprotein (LDL), dan trigliserida serta rendahnya kadar high density lipoprotein (HDL). Kolesterol LDL sangat berperan dalam menyebabkan proses aterosklerosis, sedangkan kolesterol HDL mampu melindungi pembuluh darah terhadap terjadinya aterosklerosis (antiaterogenik). Hal ini memberikan penjelasan bahwa peningkatan kadar kolesterol LDL dan menurunnya kadar kolesterol HDL dapat meningkatkan risiko terjadinya PJK. ${ }^{7,8}$

Penelitian Monitoring Trends and Determinants in Cardiovascular Disease (MONICA) di Jakarta pada tahun 1988 menunjukkan bahwa kadar rerata kolesterol total pada perempuan ialah $206.6 \mathrm{mg} / \mathrm{dl}$ dan laki-laki 199,8 mg/dl, sedangkan pada tahun 1993 ditemukan peningkatan kadar rerata kolesterol total menjadi $213,0 \mathrm{mg} / \mathrm{dl}$ pada perempuan dan $204,8 \mathrm{mg} / \mathrm{dl}$ pada lakilaki. $^{6}$

Berdasarkan beberapa penelitian sebelumnya yang menunjukkan bahwa SKA merupakan salah satu penyebab kematian tertinggi di dunia dan di Indonesia, disertai dengan besarnya pengaruh profil lipid terhadap penyakit ini, 
maka penulis tertarik untuk melakukan penelitian mengenai gambaran profil lipid pada pasien dengan jenis kelamin wanita yang didiagnosis SKA di RSUP Prof. Dr. R. D. Kandou Manado pada tahun 20122013.

\section{METODE PENELITIAN}

Jenis penelitian ini ialah deskriptif retrospektif dengan desain potong lintang. Populasi penelitian ialah semua penderita berjenis kelamin wanita yang didiagnosis SKA di RSUP Prof. Dr. R. D. Kandou Manado pada tahun 2012-2013. Subyek penelitian mencakup seluruh populasi dengan kriteria semua pasien berjenis kelamin wanita yang didiagnosis SKA dengan kelengkapan data rekam medis. Kriteria subyek ialah data rekam medis lengkap yaitu terdapat nama dan usia pasien, SKA sebagai diagnosis utama, serta data pemeriksaan laboratorium profil lipid (kolesterol total, trigliserida, LDL, dan HDL). Pengolahan data dilakukan dengan SPSS 22.0 menggunakan data rekam medis berdasarkan variabel yang dibutuhkan dari penelitian ini.

\section{HASIL PENELITIAN}

Dari penelitian didapatkan sebanyak 81 pasien yang memenuhi kriteria penelitian dari keseluruhan pasien berjenis kelamin wanita yang didiagnosis SKA di RSUP Prof. Dr. R. D. Kandou Manado periode tahun 2012-2013.

\section{Kolesterol total}

Dari Tabel 1 dapat dilihat bahwa frekuensi terbanyak pasien SKA ialah pasien dengan kadar kolesterol total >200 $\mathrm{mg} / \mathrm{dl}$.

HDL

Dari Tabel 2 dapat dilihat bahwa frekuensi terbanyak pasien SKA ialah pasien dengan kadar HDL <40 mg/ dan frekuensi terendah pasien SKA ialah pasien dengan kadar HDL $\geq 60$ mg/dl.
Tabel 1. Distribusi frekuensi kadar kolesterol total pasien SKA

\begin{tabular}{lcc}
\hline \multicolumn{1}{c}{$\begin{array}{c}\text { Kolesterol total } \\
\text { (mg/dl) }\end{array}$} & Frekuensi & \% \\
\hline$\geq 240$ & 25 & 30,9 \\
$200-239$ & 27 & 33,3 \\
$<200$ & 29 & 35,8 \\
Jumlah & 81 & 100 \\
\hline
\end{tabular}

Tabel 2. Distribusi frekuensi kadar kolesterol HDL pasien SKA

\begin{tabular}{lcc}
\hline \multicolumn{1}{c}{$\begin{array}{c}\text { Kolesterol HDL } \\
\text { (mg/dl) }\end{array}$} & Frekuensi & \% \\
\hline$<40$ & 51 & 63 \\
$40-59$ & 23 & 38,4 \\
$\geq 60$ & 7 & 8,6 \\
Jumlah & 81 & 100 \\
\hline
\end{tabular}

\section{Low density lipoprotein (LDL)}

Dari Tabel 3 dapat dilihat bahwa frekuensi terbanyak pasien SKA ialah pasien dengan kadar kolesterol LDL >160 $\mathrm{mg} / \mathrm{dl}$ dan frekuensi terendah pasien SKA ialah pasien dengan kadar LDL $<100$ $\mathrm{mg} / \mathrm{dl}$.

Tabel 3. Distribusi frekuensi kadar kolesterol LDL pasien SKA

\begin{tabular}{lcc}
\hline \multicolumn{1}{c}{$\begin{array}{c}\text { Kolesterol LDL } \\
(\mathbf{m g} / \mathbf{d l})\end{array}$} & Frekuensi & \% \\
\hline$<100$ & 12 & 14,8 \\
$100-129$ & 19 & 23,5 \\
$130-159$ & 15 & 18,5 \\
$>160$ & 35 & 43,2 \\
Jumlah & 81 & 100 \\
\hline
\end{tabular}

\section{Trigliserida}

Dari Tabel 4 dapat dilihat bahwa frekuensi terbanyak pasien SKA ialah pasien dengan kadar trigliserida $<150$ $\mathrm{mg} / \mathrm{dl}$ dan frekuensi terendah pasien SKA ialah pasien dengan kadar trigliserida $\geq 400$ $\mathrm{mg} / \mathrm{dl}$. 
Tabel 4. Distribusi frekuensi kadar trigliserida pasien SKA

\begin{tabular}{lcc}
\hline Trigliserida (mg/dl) & Frekuensi & \% \\
\hline$<150$ & 42 & 51,9 \\
$150-199$ & 25 & 30,9 \\
$200-399$ & 13 & 16 \\
$\geq 400$ & 1 & 1,2 \\
Jumlah & 81 & 100 \\
\hline
\end{tabular}

\section{Sindroma koroner akut}

Dari Tabel 5 dapat dilihat bahwa gambaran kejadian terbanyak SKA di RSUP Prof. Dr. R. D. Kandou Manado pada tahun 2012-2013 ialah kejadian angina pektoris tak stabil, selanjutnya kejadian STEMI, dan yang terendah ialah kejadian NSTEMI.

Tabel 5. Gambaran kejadian SKA

\begin{tabular}{lcc}
\hline \multicolumn{1}{c}{ SKA } & Frekuensi & \% \\
\hline $\begin{array}{l}\text { Angina pektoris tak } \\
\text { stabil }\end{array}$ & 38 & 46,9 \\
NSTEMI & 15 & 18,5 \\
STEMI & 28 & 34,6 \\
Jumlah & 81 & 100 \\
\hline
\end{tabular}

\section{Usia}

Dari Tabel 6 dapat dilihat bahwa frekuensi terbanyak pasien yang menderita SKA yang dijadikan subjek penelitian berada pada kelompok umur 51-60 tahun dan yang terendah berada pada kelompok usia $<40$ tahun.

Tabel 6. Distribusi frekuensi usia pasien SKA

\begin{tabular}{lcc}
\hline \multicolumn{1}{c}{ Usia (tahun) } & Frekuensi & \% \\
\hline$<40$ & 2 & 2,5 \\
$41-50$ & 8 & 9,9 \\
$51-60$ & 29 & 35,8 \\
$61-70$ & 21 & 25,9 \\
$>70$ & 21 & 25,9 \\
Jumlah & 81 & 100 \\
\hline
\end{tabular}

Penelitian ini juga menunjukkan diabetes melitus ditemukan pada 24 pasien $(29,6 \%)$ dan hipertensi ditemukan pada 58 pasien $(71,6 \%)$, sedangkan rerata lama perawatan di rumah sakit (Length of stay/LOS) ialah $8,44 \pm 4,36$ hari. Selain itu, penelitian juga menunjukkan bahwa kadar kolesterol total, LDL dan trigliserida yang tinggi, serta ditemukannya penyakit penyerta (DM serta hipertensi) dan juga kadar HDL yang rendah merupakan faktorfaktor yang secara signifikan menyebabkan peningkatan lama perawatan di rumah sakit.

\section{BAHASAN}

Hasil penelitian mendapatkan bahwa frekuensi terbanyak pasien SKA di RSUP Prof. Dr. R. D. Kandou Manado pada tahun 2012-2013 ialah pasien dengan kolesterol total >200 mg/dl sebanyak 52 pasien $(64,2 \%)$ (Tabel 1). Kadar kolesterol total darah yang sebaiknya ialah $<200 \mathrm{mg} / \mathrm{dl}$ karena bila >200 mg/dl maka kolesterol tersebut akan disimpan dan menempel didalam pembuluh darah sehingga nantinya akan menimbulkan pengendapan kolesterol di dalam pembuluh darah; hal tersebut menyebabkan risiko untuk terjadinya PJK semakin meningkat. Secara klinis digunakan kolesterol total untuk menentukan faktor risiko penyakit jantung, walau secara patofisiologi yang berperan sebagai faktor risiko ialah kolesterol LDL. ${ }^{9}$

Dari hasil penelitian didapatkan frekuensi terbanyak pasien SKA di RSUP Prof. Dr. R. D. Kandou Manado pada tahun 2012-2013 ialah pasien dengan kolesterol HDL $<40 \mathrm{mg} / \mathrm{dl}$ sebanyak 51 pasien (63\%) (Tabel 2). Hasil ini sesuai dengan penelitian oleh Cordero ${ }^{11}$ yang menunjukkan hasil frekuensi kolesterol HDL terbanyak ialah $<40 \mathrm{mg} / \mathrm{dl}(71,6 \%)$.

Hasil penelitian bahwa frekuensi terbanyak SKA ialah pasien dengan kadar kolesterol HDL rendah ( $<40 \mathrm{mg} / \mathrm{dl})$ sesuai dengan acuan pustaka. Kolesterol HDL berfungsi untuk mengambil kolesterol yang tersimpan di dalam makrofag kembali ke hati. Kolesterol HDL menghalangi proses 
aterosklerosis secara langsung dengan menghilangkan kolesterol dari sel busa (foam cell), menghambat oksidasi kolesterol LDL, serta membatasi proses peradangan yang mendasari aterosklerosis. Penurunan kadar kolesterol HDL akan mengurangi peran kolesterol HDL sebagai penangkap kolesterol pada pengangkutan balik kolesterol dari jaringan ke hati, sehingga kolesterol yang menumpuk di sepanjang dinding pembuluh darah tidak diangkut kembali ke hati. Hal tersebut akan menyebabkan pembentukan plak karena penumpukan kolesterol di sepanjang dinding pembuluh darah (aterosklerosis). ${ }^{8,9}$

Penelitian ini mendapatkan frekuensi terbanyak pasien SKA di RSUP Prof. Dr. R. D. Kandou Manado pada tahun 20122013 ialah pasien dengan kadar LDL >160 $\mathrm{mg} / \mathrm{dl}$ sebanyak 35 pasien $(43,2 \%$ ) (Tabel 3 ). Menurut acuan pustaka, kadar kolesterol LDL >130 mg/dl akan meningkatkan risiko terjadinya PJK. LDL yang ada di dalam plasma akan mengalami oksidasi lalu ditangkap oleh makrofag yang akan menjadi sel busa. Hal ini yang mendasari proses terjadinya aterosklerosis pada PJK. Makin banyak LDL dalam plasma, makin banyak yang mengalami oksidasi dan ditangkap oleh sel makrofag. Jumlah kolesterol yang akan teroksidasi tergantung dari kadar kolesterol yang terkandung di LDL. Bila kadar kolesterol LDL tinggi maka akan menumpuk di dinding arteri dan teroksidasi kemudian difagositosis oleh sel busa dalam suatu proses yang mengarah pada aterosklerosis. ${ }^{8,9,12}$

Dari hasil penelitian didapatkan frekuensi terbanyak pasien SKA di RSUP Prof. Dr. R. D. Kandou Manado pada tahun 2012-2013 ialah pasien dengan kadar trigliserida $<150 \mathrm{mg} / \mathrm{dl}$ sebanyak 42 pasien $(51,9 \%)$ (Tabel 4). Hasil ini sesuai dengan penelitian Manurung ${ }^{10}$ yang mendapatkan bahwa frekuensi terbanyak ialah kadar trigliserida $<150 \mathrm{mg} / \mathrm{dl}$ sebanyak 226 pasien $(57,8 \%)$.

Menurut acuan pustaka, kadar trigliserida yang tinggi $(>200 \mathrm{mg} / \mathrm{dl})$ merupakan faktor risiko untuk terjadinya PJK. Trigliserida merupakan lemak utama dalam makanan. Setelah sampai di usus, trigliserida akan dikemas dalam bentuk kilomikron dan mengalami hidrolisis oleh enzim lipoprotein lipase menjadi asam lemak bebas yang akan dibawa ke hati menjadi trigliserida hati. Trigliserida dan kolesterol di hati akan disintesis menjadi kolesterol very low density lipoprotein (VLDL) kemudian dibawa di dalam darah. Kolesterol VLDL diubah menjadi bentuk kolesterol intermediate density lipoprotein (IDL) dan selanjutnya menjadi kolesterol LDL yang bila teroksidasi nantinya akan mendasari proses aterosklerosis, sehingga kadar trigliserida memengaruhi proses aterosklerosis pada PJK. ${ }^{9,12}$

SKA merupakan penyakit yang multifaktorial, sehingga banyak faktor risiko yang dapat memengaruhinya. Tidak hanya hiperkolesterolemia tetapi juga merokok, hipertensi, obesitas, DM, faktor keturunan, dan faktor risiko lainnya. ${ }^{13}$ Hal tersebut sesuai dengan hasil penelitian yang mendapatkan bahwa DM dan hipertensi banyak ditemukan pada wanita dengan SKA. Penelitian juga menunjukkan bahwa peningkatan lama perawatan di rumah sakit berhubungan dengan kadar kolesterol total, LDL, dan trigliserida yang tinggi, serta ditemukannya penyakit penyerta (DM serta hipertensi) dan kadar HDL yang rendah. Selain itu, endapan lemak yang terdapat di pembuluh darah dapat terbentuk jauh sebelum serangan terjadi yang nantinya akan mengalami ruptur hingga menyebabkan sumbatan pada pembuluh darah. Hal ini menjelaskan bahwa kadar lipid yang tinggi dapat terjadi pada saat proses aterosklerosis yaitu jauh sebelum terjadinya serangan. ${ }^{14}$

Secara presentase, dari hasil penelitian ini didapatkan gambaran kejadian SKA terbanyak di RSUP Prof. Dr. R. D. Kandou Manado pada tahun 2012-2013 ialah angina pektoris tak stabil $(46,9 \%)$ diikuti STEMI $(34,6 \%)$, dan NSTEMI $(18,5 \%)$ (Tabel 5). Menurut acuan pustaka, tingginya kasus angina pektoris tak stabil serta NSTEMI dibanding STEMI karena tingginya usaha pengelolaan penyakit dan upaya pencegahan penyakit kardiovaskuler. ${ }^{15}$ 
Secara presentase, dari hasil penelitian ini didapatkan kelompok usia terbanyak pasien wanita dengan SKA di RSUP Prof. Dr. R. D. Kandou Manado pada tahun 2012-2013 ialah 51-60 tahun (35,8\%) (Tabel 6). Menurut acuan pustaka, insiden SKA meningkat saat usia $>45$ tahun pada laki-laki dan usia >55 tahun pada perempuan. Kerentanan individu terhadap aterosklerosis koroner meningkat seiring bertambahnya usia. Pada usia 40-60 tahun insiden infark miokard meningkat sebanyak lima kali lipat. Hal ini sesuai dengan hasil penelitian Capewell et al. ${ }^{16}$ bahwa kelompok usia terbanyak pasien yaitu 45-54 tahun.

Risiko aterosklerosis koroner lebih besar pada laki-laki daripada perempuan. Perempuan relatif lebih kebal terhadap penyakit ini sampai usia setelah menopause, dan kemudian menjadi sama rentannya seperti pada laki-laki. Efek perlindungan estrogen dianggap menjelaskan adanya imunitas wanita pada usia sebelum menopause yaitu melindungi pembuluh darah dari kerusakan. ${ }^{16}$

Limitasi penelitian ini ialah:

1. Penelitian ini hanya mengkaji 1 faktor risiko dari penyakit SKA

2. Data hasil pemeriksaan profil lipid pada pasien dengan SKA yang tidak sesuai dengan acuan pustaka bisa disebabkan karena pasien telah mendapatkan pengobatan sebelumnya.

3. Data pertama hasil pemeriksaan profil lipid tidak dapat menjadi satu-satunya tolok ukur untuk melihat faktor risiko dislipidemia pada pasien, karena perlu diperhatikan hasil pemeriksaan profil lipid jauh sebelum terjadinya SKA.

\section{SIMPULAN}

Dari hasil penelitian terhadap profil lipid pasien berjenis kelamin wanita dengan SKA di RSUP Prof. Dr. R. D. Kandou Manado tahun 2012-2013 dapat disimpulkan bahwa:

1. Jumlah pasien SKA yang memiliki kadar kolesterol total tinggi lebih banyak daripada yang memiliki kadar kolesterol total normal.

2. Jumlah pasien SKA yang memiliki kadar HDL rendah lebih banyak daripada yang memiliki kadar HDL normal.

3. Jumlah pasien SKA yang memiliki kadar LDL tinggi lebih banyak daripada yang memiliki kadar LDL normal.

4. Jumlah pasien SKA yang memiliki kadar trigliserida tinggi lebih sedikit daripada yang memiliki kadar trigliserida normal.

5. Kasus SKA terbanyak ialah angina pektoris tak stabil kemudian STEMI dan yang paling sedikit ialah NSTEMI.

6. Usia terbanyak pada pasien SKA ialah 51-60 tahun.

\section{DAFTAR PUSTAKA}

1. Smith SC, Jackson R, Pearson TA, Fuster V, Yusuf S, Faergeman $O$, et al. Principles for national and regional guidelines on cardiovascular disease prevention: a scientific statement from the world heart forum. Circulation. 2004;109:3112-21.

2. Kumar A, Cannon CP. Acute Coronary Syndromes: Diagnosis and Management, Part I. Symposium on Cardiovascular Diseases. Mayo Clinic Proceedings, 2009; p. 917-38.

3. Larosa JC. Prevention and treatment of coronary heart disease. Circulation. 2001;104:1688-92.

4. Bassand JP, Hamm CW, Ardissino D. Guideline for the diagnosis and treatment of non-ST segment acute coronary syndrome.The Task Force for the Diagnosis and treatment of Non-ST Elevation Acute Coronary Syndrome of the Europe Society of Cardiology. Eur Heart J. 2007; (28):1598-660.

5. Departemen Kesehatan RI. Survei kesehatan nasional 2001: laporan studi mortalitas 2001: pola penyakit penyebab kematian di Indonesia. Jakarta: Badan Penelitian dan Pengembangan Kesehatan, 2003; p. 76.

6. Kementrian Kesehatan RI. 2012. Gambaran penyakit tidak menular di rumah sakit di Indonesia tahun 2009 dan 2010. Jakarta: Pusat Data dan Informasi Kemenkes RI, 2012; p. 48. 
7. Joshi P, Islam S, Pais P, Reddy S, Dorairaj P, Kazmi K, et al. Risk factors for early myocardial infarction in South Asians compared with individuals in other countries. JAMA. 2007;297:286-94.

8. Barter P. The Role of HDL-cholesterol in preventing atherosclerotic disease. Eur Heart J Suppl. 2005;7(suppl F):F4-F8.

9. Austin MA, Rodriguez BL, McKnight B, McNeely MJ, Edwards KL, Curb JD, et al. Low-density lipoprotein particle size, triglycerides, and high density lipoprotein cholesterol as risk factors for coronary heart disease in older JapaneseAmerican men. Am J Cardiol. 2000;86: 412-6.

10. Manurung D. Lipid profiles of acute coronary syndrome patients hospitalized in ICCU of Cipto Mangunkusumo hospital. Acta Med Indones-Indones J Intern Med. 2006;38(4):196-201.

11. Cordero A, Arribas JM, Gonzalez VB, Agudo P, Miralles B, Masia MD, et al. Low levels of high-density lipoprotein cholesterol are independently associated with acute coronary heart disease in patients hospitalized for chest pain. Rev
Esp Cardiol. 2012;65:305-8.

12. Adam JMF. Dislipidemia. In: Buku Ajar Ilmu Penyakit Dalam Jilid III. Jakarta: Pusat Penerbitan Departemen Ilmu Penyakit Dalam Fakultas Kedokteran Universitas Indonesia, 2006; p. 32-35.

13. Ranjith N, Pegoraro RJ, Shanmugam R. Obesity-associated genetic variants in young Asian Indians with the metabolic syndrome and myocardial infarction. Cardiovasc J Afr. 2011;22:25-30.

14. Lindsay RS, Howard BV. Cardiovascular risk associated with the metabolic syndrome. Curr Diab Rep. 2004;4:63-8.

15. The' roux $P$, Fuster V. Acute coronary syndromes: unstable angina and non-Qwave myocardial infarction. Circulation. 1998;97:1195-206.

16. Capewell S, Ford ES, Croft JB, Critchley JA, Greenlund KJ, Labarthe DR. Cardiovascular risk factor trends and potential for reducing coronary heart disease mortality in the United States of America. Research Coronary heart disease in the United States of America. Bull World Health Organ. 2010;88:12030. 